\title{
Agnès Bénassy-Quéré
}

\section{Towards a Franco-German Approach on Euro Area's Economic Governance}

In: Nida-Rümelin, Julian / Daniels, Detlef von / Wloka, Nicole (Hrsg.): Internationale Gerechtigkeit und institutionelle Verantwortung. - ISBN: 978-3-11-061586-9. - Berlin: De Gruyter, 2019.

S. $205-217$

(Forschungsberichte / Interdisziplinäre Arbeitsgruppen, Berlin-Brandenburgische Akademie der Wissenschaften ; 41) 


\section{The Maastricht Doctrine and Its Amendments}

The Maastricht doctrine of the euro area relied on strict policy assignment, and on a triple ban. Both elements have been severely shaken by the crisis.

\section{A Policy Assignment}

The policy assignment inherited from Maastricht is extremely simple: the ECB would ensure price stability, whereas national governments would be in charge of stabilizing their own economy through fiscal policy (i.e. fiscal tightening in good times and fiscal expansion in bad times) when they are hit by specific shocks, within the limits of the Stability and growth pact (SGP).

This policy assignment did not work during the crisis, for two reasons. First, the ECB fell short of instruments to reach its objective. Aggregate inflation declined sharply despite zero interest rates and various forms of non-conventional monetary policies. Second, aggregate fiscal policy (i.e. the combination of the 19 national fiscal policies) was counter-cyclical in 2009 but turned pro-cyclical during the "second dip", in 2011-13: on average, euro area governments tightened fiscal policy when the economy was falling again (Figure 1). This reaction of fiscal policy made the crisis even more acute and jeopardized the efforts of peripheral countries to adjust their fiscal balances.

It is tempting to attribute this collective failure to past fiscal profligacy: euro area governments just did not have enough fiscal space to expand their budget in order to support the economy. However, most of the aggregate budget tightening observed in 2012 and 2013 did not come from constrained, peripheral countries, but rather from core countries that were either in the corrective arm or in the preventive arm of the SGP. Furthermore, most of the crises experienced by peripheral countries starting in 2010 did not arise due to fiscal profligacy: only Greece had a fiscal deficit of more than 3 percent of GDP before the Global financial crisis.

Because aggregate fiscal policy had turned pro-cyclical, monetary policy had to do even more easing. In 2015, the ECB started its quantitative easing pro- 
3

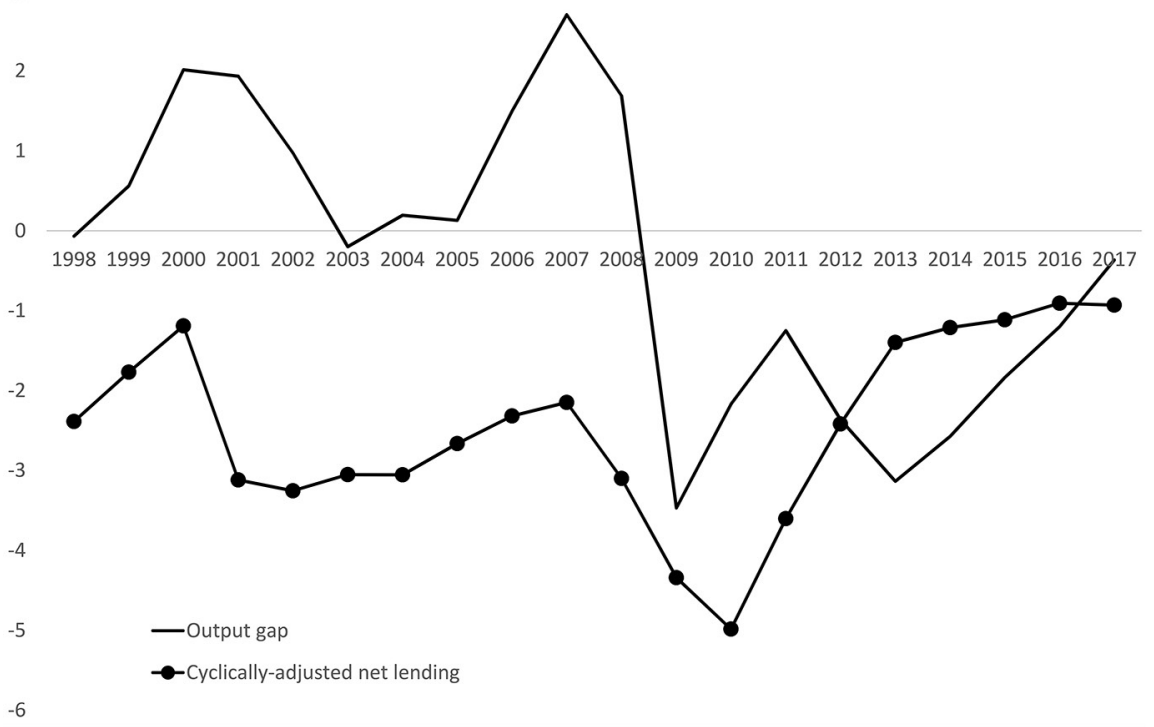

Figure 1: Aggregate fiscal policy in the euro area: cyclically-adjusted balance (in \% of GDP) against the output gap (in \% of potential GDP)

Source: Ameco database of the European Commission

gramme which spurred criticism for the large amounts of sovereign bonds purchases it involved.

Economists have long viewed the "fiscal dominance" problem as the risk that fiscal profligacy will ultimately force the central bank to monetize the deficits. In the middle of the economic crisis, a new version of the "fiscal dominance" problem appeared: since euro area governments were unable or unwilling to expand their budgets, the ECB was forced to substitute for them. When the economy resumed, after 2013, a more traditional version of fiscal dominance reemerged, in relation with the "doom loop" between sovereign risk and banking risk: to the extent that the commercial banks of a country were heavily exposed to the risk on their own sovereign, any risk arising on the latter would immediately be transmitted to the former. As a lender of last resort, the central bank is committed to maintain the liquidity but not the solvency of the banking sector. However, the concentration of sovereign risks in the banks of the country makes it difficult to separate illiquidity from insolvency, since sovereign bonds are routinely used by commercial banks to obtain liquidity at the central bank. This problem raises the risk that the central bank could be pushed to extend liquidity to an insolvent bank, or with low-quality collateral, in order to avoid the break- 
out of the euro area. This risk materialized in Greece in 2015 where the ECB regularly had to raise the cap on emergency liquidity assistance delivered by the national bank of Greece.

To make things even more dysfunctional, the Maastricht framework assigned to national governments the task to supervise their banking sector. As seen during the crisis, light supervision and regulatory capture produced massive externalities across member states and made the risk of fiscal dominance more acute.

\section{B Triple Ban}

The Maastricht framework also relied on a triple ban: no bail out, no monetization, no debt restructuring. The no bail-out rule was enshrined in the treaty as a way to protect the European taxpayers from the need to repay the debts of other member states. The no-monetization rule was also enshrined in the treaty as a way to protect monetary policy from fiscal dominance. Finally, the no-debt restructuring rule was not written anywhere but it was implicit that no euro area sovereign debt could be restructured ever.

The sustainability of the triple ban relied on the SGP: if all member states complied with the rules, there would be no need for bail-out, monetization or restructuring. However, several countries, including France and Germany, breached the SGP. More worrisome, complying with the SGP did not protect a number of countries (notably Ireland) from suffering deep financial crises and ultimately sovereign debt crises.

The Europeans managed the crisis in a pragmatic, dirty way, as they accepted a bit of the three evils: bail-out (through subsidized loans to crisis countries), monetization (through promissory notes in Ireland), and restructuring (in Greece). This outcome is not satisfactory, though, and the debate is raging about which ban should be dropped, and whether a clearer framework can be set up without triggering another crisis.

\section{Amendments to the Maastricht Doctrine}

Set up in 1992, the Maastricht doctrine has been revised several times before, during and after the crisis. The most notable amendments are the following:

- Fiscal rules have been adapted over time to make them less pro-cyclical and more stringent in good times; and to put more emphasis on the debt dynamics. 
- The banking union has harmonized bank regulations, centralized the supervision of the largest banks, harmonized the process of bank resolution, and introduced a fund to accompany bank resolutions. Today, European banks are much better capitalized than they were in the eve of the Global financial crisis.

- The creation of the European stability mechanism (ESM) has offered a scheme to extend emergency loans to a country in exchange for an adjustment programme which is supposed to ensure the solvency of the government receiving the loans.

- The Outright monetary transactions (OMTs) announced (but never used so far) by the ECB have contributed to stabilizing the euro area's economy through allowing the ECB to buy potentially unlimited amounts of sovereign bonds provided an adequate adjustment programme is agreed with the ESM. In contrast with the ESM, the ECB has unlimited capacity to lend, hence the announcement was considered credible.

Although these various reforms are extremely important, they have not entirely solved the problem of the euro area:

- For a large country like Italy, the ESM is too small, even if the Italian government were to agree on an adjustment programme. Hence, the question of debt restructuring is still there.

- The concentration of national sovereign risk in the banks has increased rather than decreased since the start of the crisis: although national government can no longer bail out their banks, the "doom loop" is still there.

- SGP rules have become extremely complex and opaque. And they have performed poorly in ensuring fiscal adjustment in a non-destabilizing way. With high debt levels, there is a risk that governments tighten their budgets during the next crisis, whereas the ECB will not yet be in a position to do much easing.

In brief, one way to solve the triple ban would be to drop the no-restructuring requirement. However, debt restructuring in a large country would impose dramatic damage on the euro area economy, through another banking crisis and contagion effects. Hence it cannot be envisaged before sovereign exposures have been reduced and diversified in the banks of the euro area. The problem is that the process of risk diversification may itself trigger a sovereign bond crisis. Hence the situation is blocked. 


\section{Franco-German Disagreements}

French and German governments traditionally have different views on how to handle the euro area and more generally macroeconomic policies. The disagreements start with different vocabularies. The main keywords in Germany are the following:

- Responsibility, to be opposed to moral hazard that would arise e. g. from a "transfer union" through the common pool problem;

- Rules, to be closely followed with little room for discretion;

- Market discipline, to be contrasted to the natural indiscipline of governments;

- Risk-reduction, to be opposed to risk-sharing. This concept covers a reduction in public and private debt levels, and a reduction in non-performing loans in the banks' balance sheets, rather than any form of risk mutualization.

- Structural reforms, that are considered the paragon of economic policy;

- Stability: and important word that de facto refers to fiscal discipline.

The key words of the French debate are a mirror image of the German ones:

- Solidarity (that Germans tend to translate into "transfer union");

- Discretion (no straight jacket for governments);

- Self-fulfilling bubbles: market discipline is doubtful;

- Fiscal stabilization, which is viewed as the paragon of economic policy;

- Central bank independence, in the sense of letting the ECB do what it needs to do in order to achieve the objective of price stability at aggregate level, even if this means extremely low interest rates for the German saver. Central bank independence used to be defended mostly in Germany, but the popularity of the concept crossed the Rhine during the crisis.

- Current account: French economists consider the extremely high current-account surplus of Germany as a major issue for the sustainability of the euro area. A current account surplus means excess supply over demand (or equivalently, excess saving over investment). Given the size of the German economy, such surplus depresses aggregate demand at the euro area level and maintains aggregate inflation at a very low level. With low inflation, the ECB is obliged to maintain an accommodative stance. More importantly, those countries having to regain competitiveness need to post negative inflation rates, which mechanically raises their debt-to-GDP ratios. 
Consistently with these two lexicons, Germany and France have entered the debate with two polar models:

- Germany: Maastricht 2.0. This model is partially inspired by the Sachverständigenrat reports as summarized in Feld et al. (2016). The idea is to come back to the Maastricht framework and make it work through: (i) automatic debt restructuring rules (possibly in the form of automatic maturity extension when a country gets ESM funding) in order to make the no bail-out clause credible, (ii) give more teeth to fiscal surveillance, possibly by moving it from the Commission to the ESM, (iii) waive the exception to the large exposure rule for sovereign risk, ${ }^{1}$ (iv) rely on structural reforms to stimulate growth, and (v) come back to more traditional monetary policy.

- France: "a euro that protects", following the expression of the candidate Emmanuel Macron during the presidential campaign of 2017. The concept covers the following elements: (i) a euro-area budget to allow for some solidarity among member states and a capacity to stabilize the economy in case of crises, (ii) symmetric adjustments within the euro area (whereas currently the adjustment falls only on deficit countries), (iii) more cooperation, e.g. in the area of digital taxation or displaced workers, in order to ensure social cohesion, (iv) an opposition to any form of automaticity in debt restructuring (that could trigger self-fulfilling crises), and (iv) no interference with the ECB.

\section{Towards a Franco-German Common Approach}

In January 2018, seven German economists and seven French economists issued a joint report proposing a consistent package of reforms that account for both German and French worries but nevertheless did not end up in a minimum denominator solution (French and German economists 2018). The German traditional view is that the governance should be rebalanced in the direction of more responsibility and less solidarity whereas the French preference would be to move in opposite direction. The Franco-German group of economists rather stated that it is possible to make progress simultaneously on both dimensions. Furthermore, they claimed that more solidarity will be necessary to enforced responsibility, and vice-versa. For instance, to make the no bail-out rule credible (responsibility), it is necessary to reinforce the euro area toolkit in terms of risk-sharing (solidarity), in the form of an extension of the ESM's remit, a euro

1 Banks are generally not allowed to hold an exposure on a specific signature in excess of 25 percent of their capital. Sovereigns benefit from a waiver to this large exposure rule. 
area deposit reinsurance mechanism and a rainy-day fund for big shocks. The group also stressed the importance of the capital market union and of reforming national fiscal rules in order to offer more flexibility to cushion economic fluctuations while ensuring more fiscal responsibility and ownership.

On June 19, 2018, Chancellor Merkel and President Macron made a joint declaration - the Meseberg declaration ${ }^{2}$ - that endorsed a relatively ambitious road map prepared by their finance ministers for the reform of the euro area and covering the following projects:

- An extension of ESM role as backstop of the single bank resolution fund and as a provider of precautionary credit lines with ex ante conditionality. The ESM would be given greater role in designing and monitoring the adjustment programmes. At a later stage it would be incorporated into EU law (instead of being an intergovernmental treaty).

- Numerical targets for non-performing loans in all banks of the euro area;

- Commitment to work on introducing Collective action clauses (CACs) with "single-limb aggregation" in Euro area sovereign debt contracts. Although technical, this measure shows the willingness of both governments to facilitate a sovereign debt restructuring.

- The start of a negotiation on the introduction of a European deposit insurance scheme (EDIS);

- A commitment to make "decisive progress" on the capital market union project;

- "A Eurozone budget within the framework of the European Union to promote competitiveness, convergence and stabilization in the euro area, starting in 2021" (all the exact terms are important), with resources coming "from both national contributions, allocation of tax revenues and European resources". A working group will be settled to examine the opportunity of a European unemployment insurance scheme (Meseberg 2018).

- A decision not to follow up on the idea of a euro area "safe asset".

This list strikes a balance between the German and French views. On the one hand, there is substantial progress in the risk-reduction dimension, with decisive action on non-performing loans and the introduction of "single limb" CACs. On the other hand, there are also elements of solidarity, with new responsibilities for the ESM as well as the start of discussions for deposit insurance and a euro area budget. Finally, the idea of a euro area "safe asset” which both governments re-

2 The meeting was taking place in Schloss Meseberg outside Berlin. 
jected partly because their own sovereign bonds are considered "safe", is sidelined.

The Meseberg declaration was received unevenly across academic circles (see Merler 2018). Some experts considered it lacked ambition, other that it was a small but decisive step in the good direction. As a matter of facts, the declaration was watered down in the euro area Summit of June 29, 2018. While the decisions to use the ESM as a fiscal backstop to the single bank resolution fund, and to start negotiations on EDIS were confirmed, most of the other elements were drowned in a rather vague "The Eurogroup will further discuss all the items mentioned in the letter by the Eurogroup President" (Euro Summit Declaration, 29 June 2018).

\section{The German-French Couple Overtaken by the Dutch-Italian One?}

While the positions of Germany and France were slowly converging in 2018, they became to no longer represent the polar views on the euro area. Instead, two hard lines appeared: the "new Hanseatic League" lead by the Netherlands, and the Italian view.

The "new Hanseatic League" was launched in November 2017, initially as a side effect of Brexit: eight Northern European countries ${ }^{3}$ decided to joint their efforts to compensate for the departure of the UK that had traditionally pushed in favor of free-market policies, with which they were generally in agreement. Just after the Meseberg declaration was released, the Dutch finance minister sent a letter to the President of the Eurogroup on behalf of 12 member states, ${ }^{4}$ approving the completion of the banking union but insisting on their disagreement on a euro area budget.

Simultaneously, the "Italian view" of euro area reforms became more vocal. Respected scholars such as Bini Smaghi or Tabellini (2018) vigorously contested the proposals of the 14 German-French experts. In particular, they argued that making sovereign debt restructuring a possibility in last resort would trigger a debt run, and that breaking the "doom loop" between sovereign risk and banking risk by penalizing excess concentration of sovereign exposures would be destabilizing. Bini Smaghi and Marcussen (2018) proposed a scheme in order to

3 The Netherlands, Ireland, Sweden, Denmark, Finland, and the three Baltic states.

4 Belgium, Luxembourg, Austria, Sweden, Denmark, Finland, Latvia, Lithuania, Estonia, Ireland, Malta and the Netherlands. 
move from the present situation (where debt restructuring would likely trigger a major euro-wide, banking crisis) and another equilibrium where part of sovereign debts would be junior whereas the other part would not be subject to restructuring.

These polar views show that, after the Franco-German agreement of Meseberg, there are still major disagreements within the euro area, some of which are even more acute than between Germany and France.

\section{A Possible Way Forward}

The debates on euro area reforms have so far focused essentially on fiscal and banking issues. The fundamental question of how to ensure non-divergent economic paths has been often left aside.

The world has dramatically changed since the Maastricht treaty was signed in 1992. Today, the European Union faces all sorts of threats, from trade to security, from legal prosecutions to political destabilization, from technologic change to political extremism. These major changes have raised the value of the EU as a single market, single trade block, single currency. However these achievements are no longer sufficient. The EU (or the euro area) needs to behave as a big player in areas such as taxation, security, or migrations and development. What recent years have evidenced is that coordination of national policies is extremely difficult and fragile. In areas that are vital for the EU (or the euro area), there is no other solution than integration. The problem is that Eurosceptic parties are on the rise, so further integration is necessary but unlikely.

Taking the opportunity of the negotiations on the new multiannual financial framework of the EU, Germany and France could propose a new European contract around the notions of stability and subsidiarity.

\section{A Stability}

In a more uncertain world, there is a need for more protection. The private sector already insures many risks. National governments, with their budgets, can insure additional risks such as unemployment resulting from "normal" business cycles, epidemics, or local natural disasters. However, they cannot insure very large shocks: in the event of a very large crisis, market access may become difficult, hence a government may not be able to borrow in order to stabilize the economy.

The strength of the EU is its diversity: to the extent that not all countries are hit by the same shocks, the EU can deliver additional insurance. This is already 
the idea behind the banking union and the capital market union. The first step is to complete the banking union and to accelerate the capital market union project so that credit will continue to flow to healthy businesses in a country even when this country is hit by a sovereign or economic crisis.

One controversial element of the banking union is the European deposit insurance scheme (EDIS). To avoid a deposit flight in case of a crisis in a country, national deposit insurance needs to be backed by a European layer, funded by the euro area banking sector. Introducing EDIS would be a major step in terms of European integration, since any depositor across the euro area would benefit from exactly the same protection. The risks of mutualizing the consequences of ill bank management will be limited by the new resolution rules: in case of a banking crisis, it is unlikely that the resolution requires hitting insured depositors. Some experts have even argued that, with the new resolution rules, EDIS would no longer be required. The flip side is that it would be highly symbolic but with limited risk involved de facto.

Even more controversial is the idea of a stabilizing euro area budget. The 14 Franco-German experts have proposed a small rainy-day fund that would accumulate resources and delivered one-off transfers to countries hit by severe crises, in order to help compensate the unemployed and to keep public investment flowing. The Meseberg declaration points to a variant of this proposal, where contributions to the fund could be suspended during a severe crisis. The common idea is that concentrating on big shocks allows a very small fund (in the order of 0.1 percent of GDP per year, possibly with a cap) to make a difference in macroeconomic terms in the event of a severe crisis. It also minimizes the moral hazard since no permanent transfers would be involved.

More generally, there is a need to make the EU budget more flexible and contingent. Hence to go away from the juste retour logic. The distribution of the funds across the member states will be known ex post only, when the different types of risks have materialized. For instance, a country hit by a sudden inflow of refugees should receive swift and generous help from the EU.

However, stability is also (and probably mainly) a result of domestic policies. In this respect, the introduction, in 2011, of the European semester, and more specifically, of the Macroeconomic imbalances procedure (MIP) 5 to monitor macroeconomic policies in EU member states was a good idea. Unfortunately, it largely got lost in translation (Alcidi/Gros 2015; Bénassy-Quéré 2015; Darvas/ Leandro 2015). Today, the MIP covers a wide range of indicators whose relation

5 "Six-pack" legislative package consisting of five regulations and a directive adopted in October 2011. 
with the risk of a macroeconomic crisis is sometimes weak. The building up of a macro-prudential policy setting was also a good initiative to reduce the risk of destabilizing financial cycles. However, there is a need for coordinating these policies both across the member states and with the MIP (Bénassy-Quéré 2018).

One controversial element is the recognition that large current-account imbalances at country level - be there deficits or surpluses - constitute a risk for the euro area. All countries that were severely hit by the euro area crisis after the Global financial crisis had posted a current-account deficit in excess of 6 percent of GDP in 2007. Large current-account surpluses are the counterparts of large current-account deficits. Furthermore, as argued above, large surpluses put deflationary pressure on the monetary union, hence they constrain monetary policy to remain loose and they make real price adjustments difficult in deficit countries. Finally, large surpluses may trigger aggressive trade policies in third countries, as has been evidenced with the Trump administration.

It is sometimes argued that the current account is beyond the control of a government. This is only partly true. The current account is the sum of excess savings over investments in the public and in the private sector. The government has control over net savings in the public sector. As for net savings in the private sector, they may be influenced by public policies. In Germany, for instance, the large amount of excess savings in the non-financial corporate sector has to do with wage moderation, tax reforms and the energy policy.

Hence, there is a responsibility of each country to "put its house in order" not only through structural reforms, but also through sustainable macroeconomic policies. The MIP could contribute to this objective provided it is dramatically streamlined to concentrate on those items directly related to the risk of a crisis.

\section{B Subsidiarity}

The subsidiarity principle is defined in Article 5 of the Maastricht treaty: "in areas which do not fall within its exclusive competence, the Union shall act only if and insofar as the objectives of the proposed action cannot be sufficiently achieved by the member states, either at central level or at regional and local level, but can rather, by reason of the scale or effects of the proposed action, be better achieved at Union level". This principle has been applied with double standards.

- $\quad$ On the one hand, the common agricultural policy, that represents around 40 percent of the EU budget, does not clearly tick the boxes of the subsidiarity principle. Although food safety and environmental standards are clearly topics with large cross-border externalities, the transfers channeled to the fam- 
ers are not mainly geared to these objectives. In November 2017, the European Council adopted a "European social pillar of social rights" which is a mixture of labor market standards and of other elements (such as childcare) whose harmonization at EU level is less compelling. Indeed, the free mobility of workers creates externalities that need to be tackled through labor market standards. In contrast, countries (or even infranational groupings) may differ widely in their preferences concerning childcare, elderly care, or paternal leave. Although these schemes do have an impact on growth, hence on the sustainability of the EU (and more specifically, of the euro area), there is a case here to let it to national governments to decide.

- On the other hand, areas with large externalities, such as energy policies or tax policies, have been mostly left to national governments. For instance, the EU carries out a single trade policy, but it accepts that each country has its own network of bilateral tax agreements with EU and non-EU countries. This mismatch creates loopholes for multinational companies, which ends up in lower tax receipts and higher social unrest. Tax cooperation has been especially painful in the EU, and the cooperation has sometimes been "forced" by non-EU pressure (United States on automatic exchange of information, OECD on measures against base erosion).

Brushing up the subsidiarity principle would be especially useful at a time when new needs emerge (security, defense, human capital...) whereas the willingness of the Europeans for integration is on the decline. This is not an easy task, as the subsidiarity principle may need to accommodate new forms of externalities that transit through political rather than economic channels. For instance, the failure of national governments to reduce local inequalities may be viewed as a purely national problem. However, to the extent that such inequalities feed Eurosceptic movements, it may be wise for the EU not to disregard them. In this area, a European tool exists but is notoriously inefficient: the European globalization adjustment fund (see Cernat/Mustilli 2017). One possibility would be to reshuffle this fund entirely to turn it into a counter that would support local initiatives of reconversion through public calls for projects and ex post evaluation. Ex post, such targeted intervention could prove less costly than some permanent policies of the European Social Fund.

\section{Conclusion}

In a rapidly changing world, the lingering governance crises in the euro area and in the EU may be perceived as a lethal. However they are also an occasion to 
brush out the objectives and the instruments of each level of integration, and to provide parsimonious responses. Germany and France have huge stakes in the future of European integration. Beyond their national lexicons, they have the capacity to complete the re-organization of the euro area and to reinvent the future of the EU. But time is running up.

\section{Bibliography}

Alcidi, Cinzia/Gros, Daniel (2015): "Economic Policy Coordination in the Euro Area under the European Semester”. In: CEPS Special Report 123, December.

Bénassy-Quéré, Agnès (2015): "Economic Policy Coordination in the Euro Area under the European Semester, In-depth Analysis". In: Report for the Economic and Monetary Affairs Committee of the European Parliament, November.

Bénassy-Quéré, Agnès (2018): "Le macro-prudentiel, un élément de plus dans l'arsenal de la politique macroéconomique de la zone euro". In: Annales des Mines, August.

Bini Smaghi, Lorenzo (2018): “A Stronger Euro Through Stronger Institutions”. In: Contribution to the Vox Euro Debate, 9 April.

Bini Smaghi, Lorenzo/Marcussen, Michala (2018): “Delivering a Safe Asset for the Euro Area: A Proposal for a Purple Bond Transition”. In: Contribution to the Vox Euro Debate, 18 July.

Cernat, Lucian/Mustilli, Federica (2017): "Trade and Labor Adjustment in Europe: What Role for the Globalization Adjustment Fund?" In: European Commission DG Trade, Chief Economic Note 2, May.

Darvas, Zsolt/Leandro, A. (2015): "The Limitations of Policy Coordination in the Euro Area under the European Semester". In: Bruegel Policy Contribution, 12 November.

Feld, Lars/Schnabel, Isabel/Schmidt, Christoph/Wieland, Volker (2016): “Maastricht 2.0: Safeguarding the Future of the Eurozone". In: Voxeu, 12 February.

French and German Economists (2018): "Reconciling Risk Sharing with Market Discipline: A Constructive Approach to Euro Area Reform". In: CEPR Policy Insight 91, January.

Merler, Silvia (2018): “The Meseberg Declaration and Euro-zone Reform”. In: Bruegel Blog Post, 25 June.

Meseberg Declaration (2018): “Renewing Europe's promises of security and prosperity" In: Presse- und Informationsamt der Bundesregierung, 19. June. https://archiv.bundesregier ung.de/archiv-de/meta/startseite/meseberg-declaration-1140806 Accessed 12.12.2018.

Tabellini, Guido (2018): “Risk Sharing and Market Discipline: What Is the Right Mix". In: Contribution to the Vox Euro Debate, 16 July. 